\title{
Studies on Some Basidiomycetes Fungi in the Forest Of Dediapada, Gujarat, India
}

\author{
Fulesh K. Kokni ${ }^{1}$, Umerfaruq M. Qureshimatva ${ }^{1}$ and Hitesh A. Solanki ${ }^{2}$ \\ (1) Research Scholar, Department of Botany, Bioinformatics and Climate Change Impact Management, \\ University School of Science, Gujarat University, Ahmedabad. \\ (2) Professor, Department of Botany, Bioinformatics and Climate Change Impact Management, University \\ School of Science, Gujarat University, Ahmedabad. \\ Email ID: koknifulesh02@gmail.com and husolanki@yahoo.com
}

\begin{abstract}
Basidiomycota is one of the most interesting and advanced group of macroscopic fungi. The Dediapada forests, constitute prime forest cover where the Gujarat State is concerned, keeping in mind that forests hardly constitute $10 \%$ of Gujarat's land area. A continue field survey was carried out in the Dediapada for the study of certain Basidiomycota fungi during the month of July-2017 to September-2017 and July-2018 to Octember-2018. Many fungi were observed, photographed, collected, studies and preserved. The present study gave a total of 94 species and 45 genera belong to 30 families of Basidiomycetes in the forest region of Dediapada, Gujarat, India.
\end{abstract}

Keywords: Fungi, Basidiomycetes, Dediapada forest, South Gujarat, India.

\section{INTRODUCTION}

The group fungi are found to be distributed everywhere i.e., cosmopolitan. Based on their different characters they are divided in to different categories. Some are lower fungi and some are higher fungi. Among all fungi, a group called Basidiomycota is one of the most interesting and advanced group of macroscopic fungi. The visual fungi of Basidiomycota include different groups, like mushrooms, puffballs, stinkhorns, bracket fungi, Polypores, jelly fungi, boletes, chanterelles, earth stars, smuts, and rusts etc.

About 80000 to 120000 species of fungi have been described to date, although the total number of species is estimated at around 1.5 million (Hawksworth, 2001; Kirk et al., 2001). The Basidiomycota contains about 30,000 species (Kirk et al. 2001). The most conspicuous and familiar Basidiomycota are those that produce mushrooms fruiting bodies, which are sexual reproductive structures. The Basidiomycota also includes yeasts (single-celled forms) and asexual species (Fell et al. 2001). Basidiomycota are found in virtually all terrestrial ecosystems, as well as freshwater and marine habitats (Kohlmeyer and Kohlmeyer, 1979; Hibbett and Binder, 2001).

A simplified, artificial classification of the Basidiomycetes

$$
\begin{aligned}
& \text { - rusts } \\
& \text { - smuts } \\
& \text { - others }
\end{aligned}
$$

- heterobasidiomycetes (divided basidium; e.g. wood ears, jelly fungi) undivided basidium)
- 'gasteromycetes' (e.g. puff balls, earth stars, stink horns, birds-nest fungi)

- 'hymenomycetes'

- Dacrymycetales

- 'Agaricales' (broad sense, e.g. mushrooms, toadstools, boletes)

- 'Aphyllophorales' (e.g. bracket and shelf fungi, corticioid fungi, toothed and spined fungi, coral fungi)

- Others

Humans have found diverse uses for Basidiomycota. Mushrooms, both cultivated and wild are eaten in many countries. For the untrained, mushroom-hunting is a risky endeavour, because some Basidiomycota produce deadly toxins (Benjamin 1995). A few mushrooms are known to be the sources of different bioactive substances like antibacterial, antifungal, antiviral, antiparasitic, antioxidant, anti-inflammatory, antiproliferative, anticancer, anti-HIV, antidiabetic and hepatoprotective substances, among others. These mushrooms have been utilized as ethnomedicines by tribal for treatment of different sicknesses (Gudikandula et al, 2015).

The State Gujarat is filled with immense diversity of flora, which have been studied and explored a lot form different part of it. Along with this there is also a great diversity of a group called Fungi in Gujarat. The South Gujarat is diversely filled with the dense distribution of fungi. The Dediapada forests, in the south of Gujarat, constitute prime forest cover. More over these forests are a part of the Shoolpaneshwar Wildlife Sanctuary. The area has assumed greater significance in recent times as it forms the major portion of the Sardar Sarovar 
submergence area. In the given scenario, the moist mixed deciduous and dry mixed deciduous forests (Champion and Seth, 1968) of this region gain importance for future preservation and conservation.

\section{MATERIALS AND METHOD}

\section{Field survey}

Most of the fleshy and gilled macro fungi were prevalent in the rainy times of the year as this time is favourable for their output, since there is ample moisture, favourable warmth, relative humidity, and sunshine, which furthermore aids the macro fungi in the decomposition of dead organic tissue. The early dry time of the year collection was predominated by the polypore's since there is decline in rainfall and relative humidity, boost in warmth, and sunshine and most of the fleshy macro fungi will not withstand these conditions. During rainy season, there is abundant growth of several kinds of Basidiomycetes. Many fungal species groups do not produce visible fruit bodies or other species-specific characteristics, or these characteristics are extremely rare and cannot be detected in traditional surveys. A continuous field survey was carried out in the region of Dediapada forest of South Gujarat. The survey was done from July-September 2017 and July-October 2018. Along with the forest area, cultivated fields and many educational campuses were also studied.

\section{Field study and Collection of Samples}

For the collection and study of samples, the manual published by the Mycology SAFRINET in (1999), The manual by Megan Prance and Nigel Fechner, Queensland Herbarium (2017) and the method given by Hailing (1996) was followed. In order to avoid the damages and scars the samples were collected with proper care and transferred in to sterile ziplocked polythene bag. Forceps, knife as well as steel spatula was used for the collection of samples. Most of the characters were noted down in field itself. A good photograph with DSLR were taken before and after collection of samples.

\section{Identification of Macro-fungi}

Seven mycological characters useful in tentative identification of mushrooms are hymenium type, cap shape, gills, stipe character, colour of the spore print, ecological type, and edibility. The species of Basidiomycota were identified by comparing the morphological characters found in the literature available (Arya, 2004) (Rajput, et al 2015), (Nagadesi \& Arya, 2014). Identification was also done by the key available in book by Thomas Lassoes (2013). Some fungi were also referred to the checklist given by Legon \& Henrici (2005).

Preservation
Samples were preserved using both dry as well as fresh method. Specimens were dried using oven and preserved fresh in $2 \%$ as well as $4 \%$ formaldehyde. The specimens preserved are submitted in the Department of Botany, Bioinformatics and Climate Change Impacts Management, Gujarat University.

\section{RESULT AND DISCUSSION}

In Basidiomycetes more than 2000 species of edible mushrooms are reported from different components of the world. People all over Asian countries in the twentieth century know that mushrooms are important bio-source of novel secondary metabolites. In India, the alternative systems of medicine utilize the curative properties of mushrooms. Secondary metabolites of these mushrooms are chemically diverse and possess a broad spectrum of biological activities, which are explored in traditional medicines. The resent study shows 71 species belonging to 33 genera of 19 families from Basidiomycetes in Dediyapada Forest division listed in Table No. 1. Agaricaceae is most dominant family with 7 genus and 23 species followed by Psathyrellaceae with 7 genus and 11 species, Marasmiceae 6 species, Lyophyllaceae 5 species and others are less than 2 species. Agaricus is the most dominant genera with 8 species followed by Marasmus 6 species, Termetomyces, Coprinellus and Leucoagaricus 5 species each and others are less than 5 species. Majority of basidiomycetes are naturally occurred on Dead decomposed parts and Soil.

\section{CONCLUSION}

Amongst the vast number of living forms very little amount of attention has been paid to conservation of fungal diversity. Due to loss of natural habitats, soil and air pollution and loss of genetic diversity many fungal species are on threat. Numerous mushrooms still stay unreported and their healthful and in addition medical advantages are unclear to us. Henceforth, an opportune examination in regard to isolation, identification, and characterization of the current mushroom vegetation is vital. The outcome of the present study elaborates the information on diversity of fungi of the study area.

\section{REFERENCES}

[1] Kirk, P.M., Cannon, P.F., David, J.C., and Stalpers, J. (2001). Ainsworth and Bisby's Dictionary of the Fungi. 9th ed. CAB International, Wallingford, UK.

[2] Fell, J. W., Boekhout, T., Fonseca, A. and Sampaio J.P. (2001). Basidiomycetous yeasts. Pp. 1-36. In: The Mycota VII. Systematics and 
Evolution. Part B. (Mclaughlin, D. J., McLaughlin, E. G. and Lemke, P. A., eds.). Springer-Verlag, Berlin.

[3] Kohlmeyer, J., and Kohlmeyer, E. (1979). Marine Mycology_The Higher Fungi. Academic Press, New York.

[4] Hibbett, D. S., and Binder, M. (2001). Evolution of marine mushrooms. Biol. Bull. 201:319-322.

[5] Benjamin, D.R. (1995). Mushrooms: poisons and panaceas. W.H. Freeman and Company, New York.

[6] Hailing RE (1996). Recommendation for collecting mushrooms for scientific. In Alexialdes MM. and JW. (sds). Selected guide lined for ethnobotanical research. A field manual, the New York botanical garden press, Bronx., pp. 135-141.

[7] Rajput, K. S., Koyani, R. D., Patel, H. P., Vasava, A. M., Patel, R. S., Patel, A. D., \& Singh, A. P. (2015). Preliminary checklist of fungi of Gujarat State, India. Current Research in Environmental \& Applied Mycology, 5(4), 285-306.

[8] Arya, A. (2004). New and interesting records of basidiomycetous fungi from Gujarat, India. Vistas in Palaeobotany and Plant Morphology: Evolutionary and Environmental Perspectives, Prof DD Pant Memorial Volume. UP Offset, Lucknow, India, 321-327.

[9] Legon, N. W., \& Henrici, A. (2005). Checklist of the British and Irish Basidiomycota. Royal Botanic Gardens.

[10]Laessoe, T. (2013). Mushrooms: How to identify and gather wild mushrooms and other fungi. DK.

[11] Gudikandula Krishna, Burra Samatha, S. V. S. S. S. L. Hima Bindu Nidadavolu, Metuku Ram Prasad, Byram Rajitha, and Maringanti Alha Singara Charaya (2015) Macrofungi in Some Forests of Telangana State, India. Journal of Mycology,

2015:

\section{PHOTO PLATES OF BASIDIOMYCOTA FUNGI}

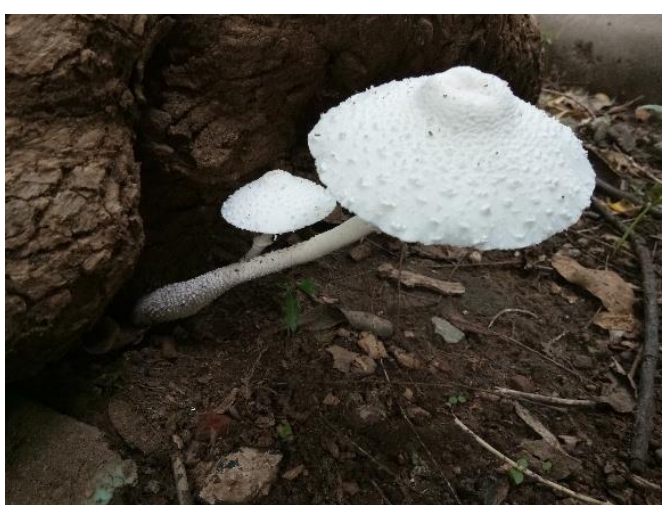

Leucocoprinus cretaceous

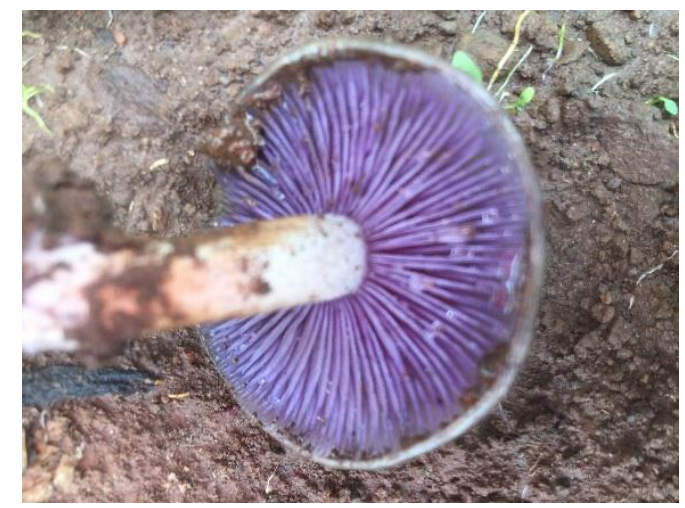

Lepista nuda

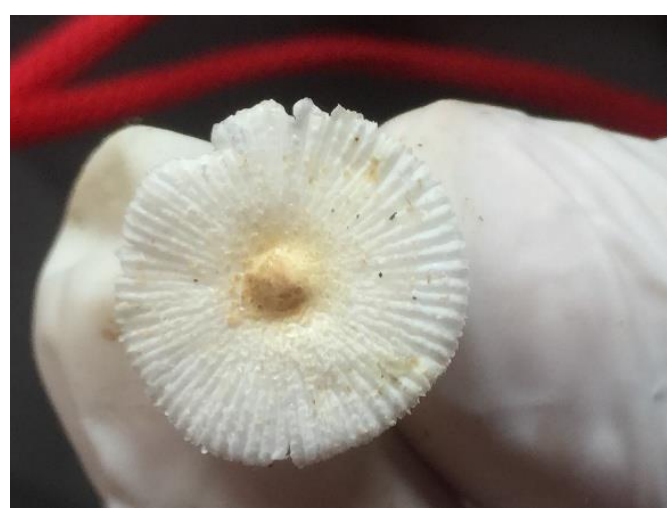

Leucocoprinus fragilissimus

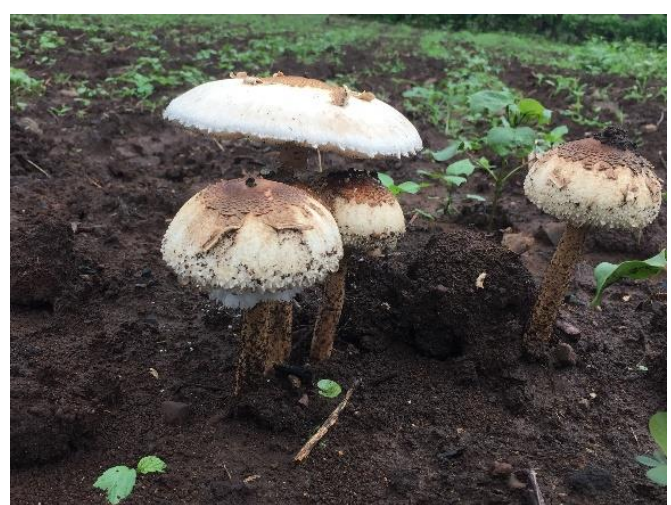

Macrolepiota procera 
International Journal of Research in Advent Technology, Vol.7, No.5, May 2019 E-ISSN: 2321-9637

Available online at www.ijrat.org

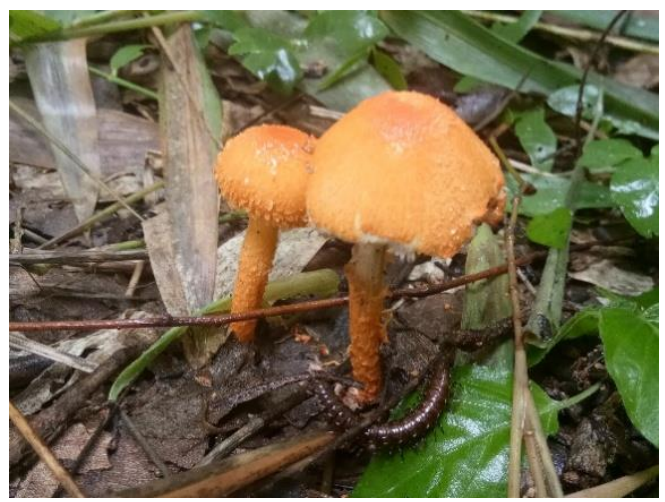

Cystoagaricus trisulpharatus

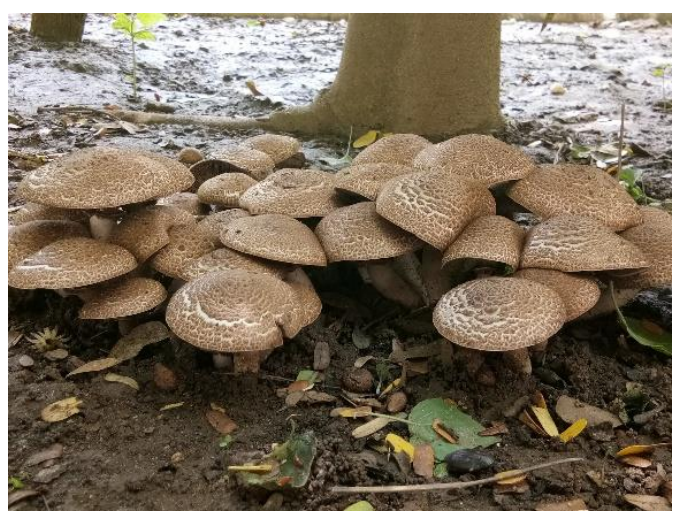

Agaricus bohusii

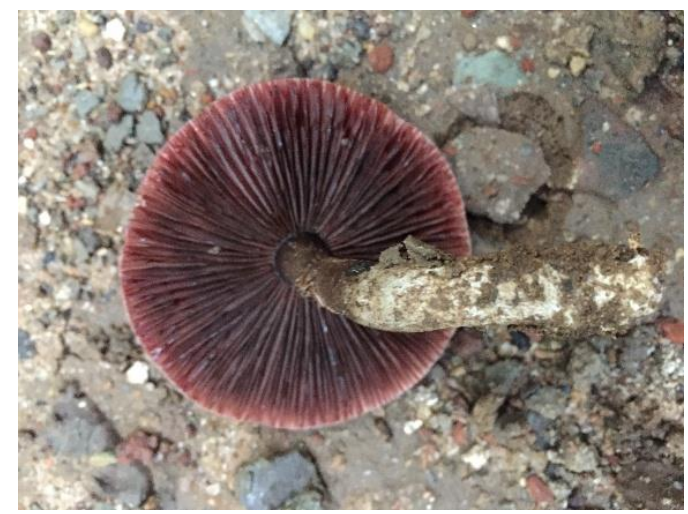

Agaricus silvaticus

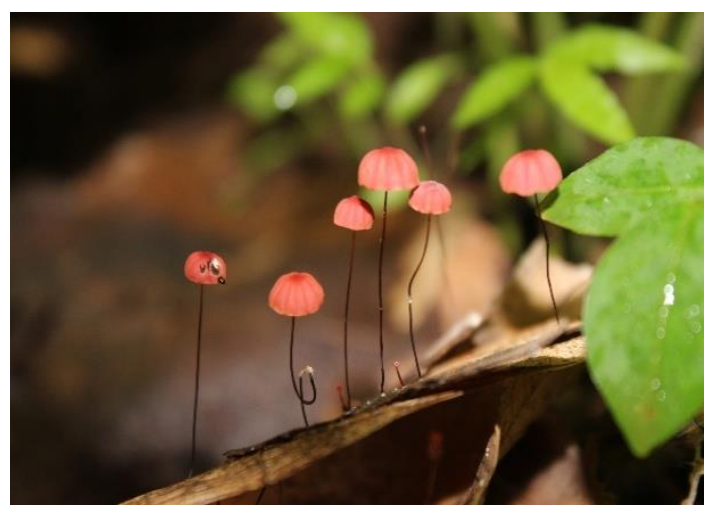

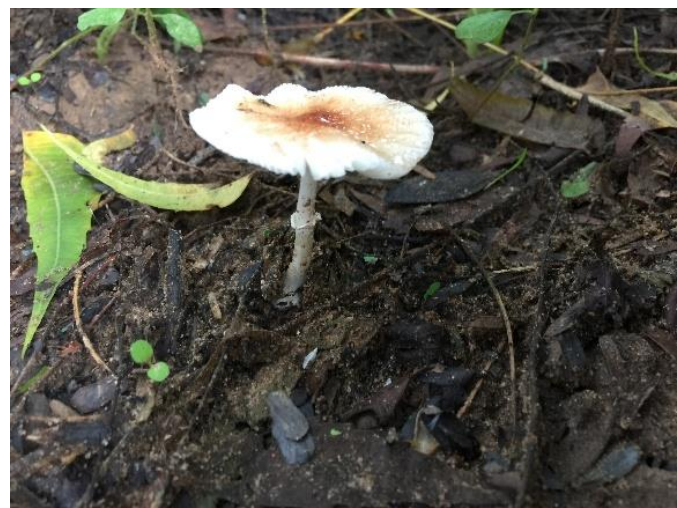

Leucoagaricus robrotinctus

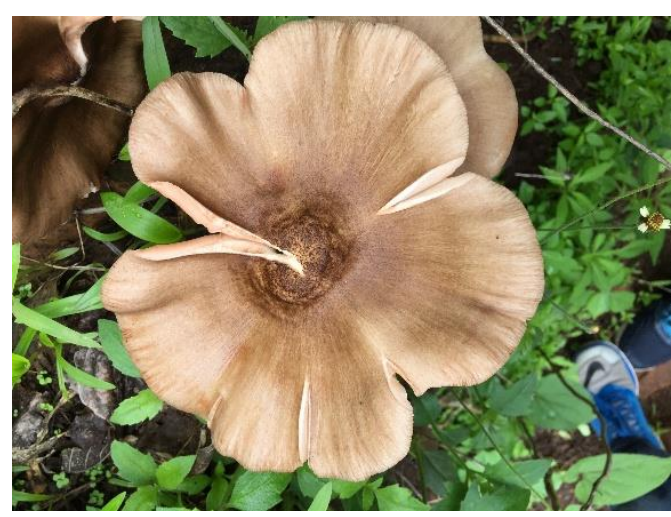

Pluteus cervinus

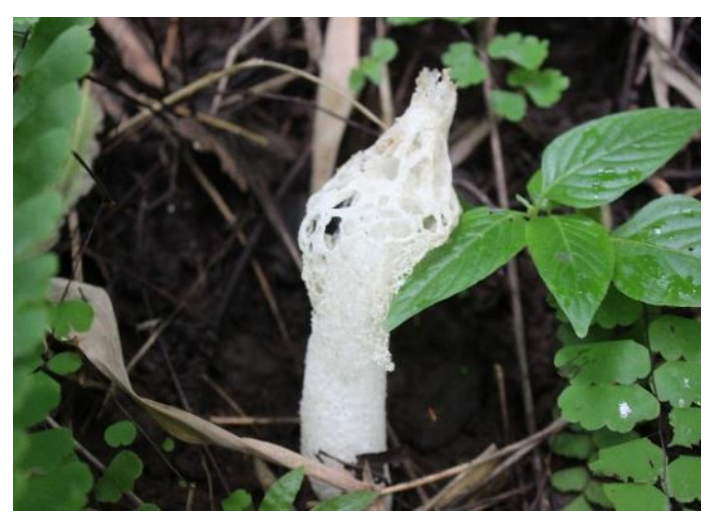

Phallus impudicus

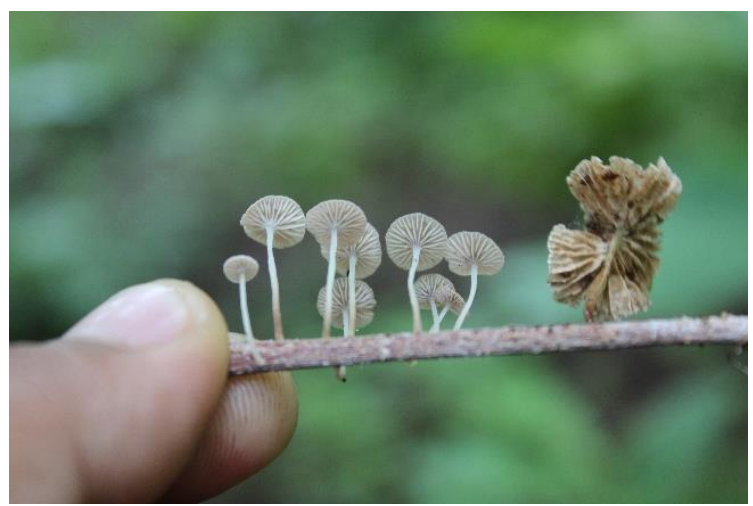


International Journal of Research in Advent Technology, Vol.7, No.5, May 2019

$$
\text { E-ISSN: 2321-9637 }
$$

Available online at www.ijrat.org

Marasmius haematocephalus

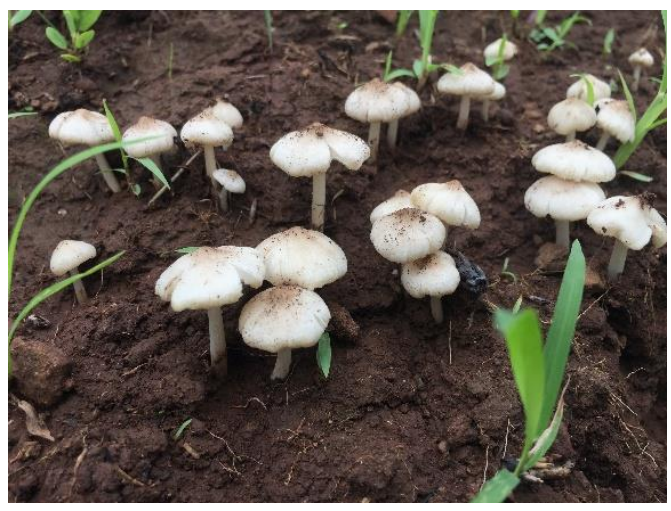

Termitomyces haemii

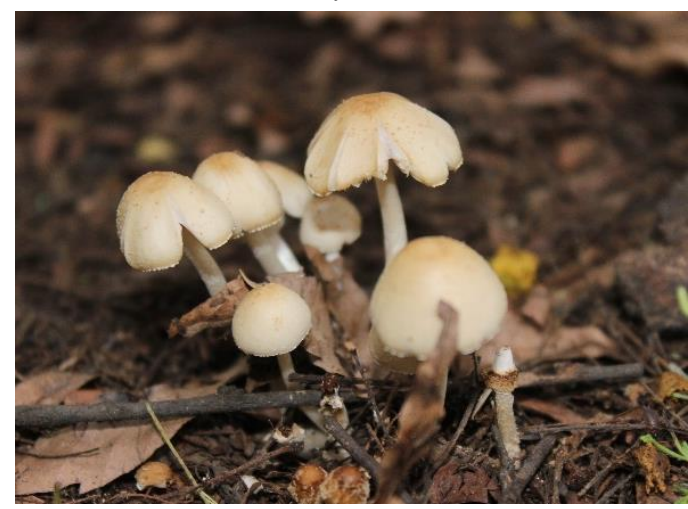

Psathyrella candolleana

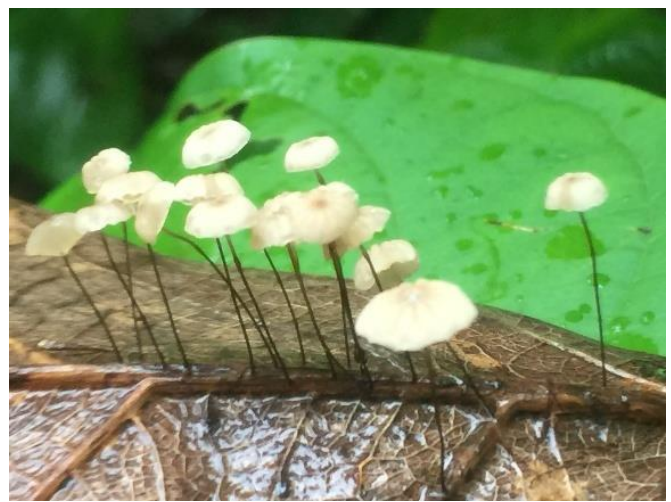

Marasmius capillaris

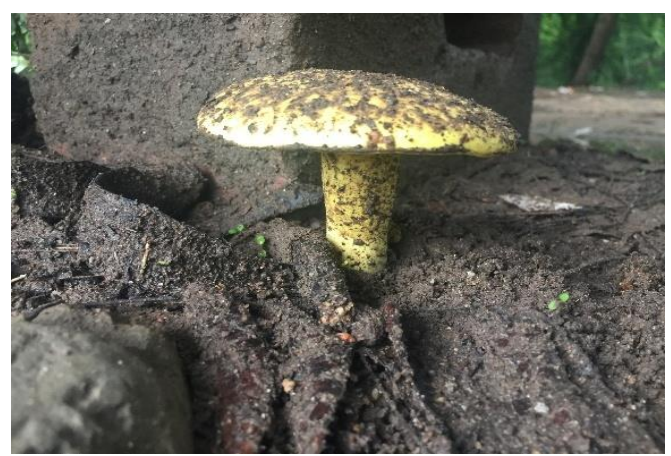

Phylloporus rhodoxanthus
Marasmius epiphyllus

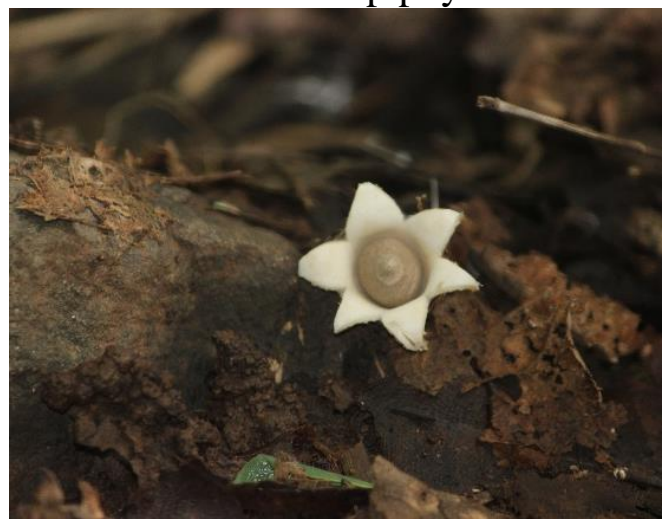

Geastrum saccatum

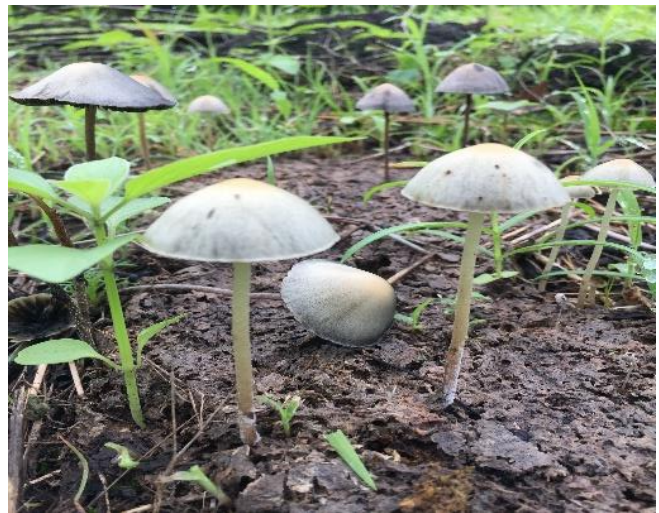

Panaeolus papilionaceous

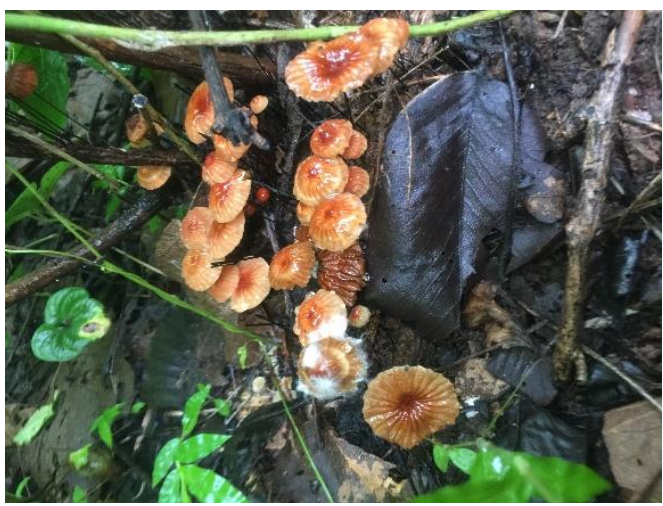

Marasmius sicus

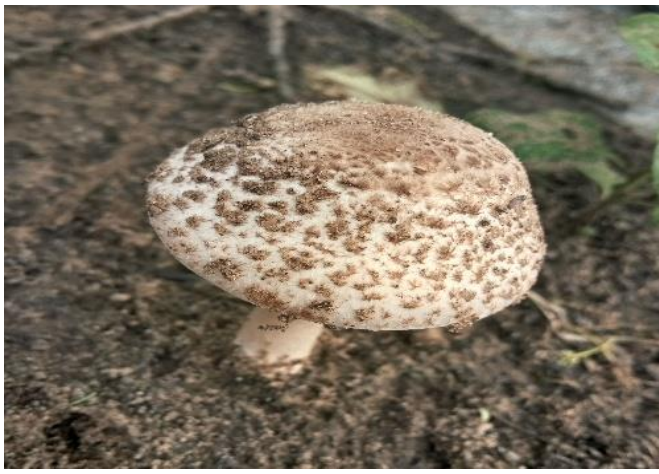

Agaricus agustus 
International Journal of Research in Advent Technology, Vol.7, No.5, May 2019

E-ISSN: 2321-9637

Available online at www.ijrat.org

Table No. 1: List of Basidiomycetes fungi found in the Dediapada region forest of South Gujarat.

\begin{tabular}{|c|c|c|c|c|c|}
\hline \multicolumn{6}{|c|}{ List of Basidiomycetes fungi found in the Dediapada region forest of South Gujarat } \\
\hline $\begin{array}{l}\text { Sr. } \\
\text { No. }\end{array}$ & Family & Genus & Species & Substratum & Location \\
\hline \multirow{23}{*}{1} & \multirow{23}{*}{ Agaricaceae } & \multirow{8}{*}{ Agaricus } & silvaticus & Soil & Dediapada, kundiamba \\
\hline & & & bitorquis & Dead decomposed part of soil & Dediapada, korvi \\
\hline & & & Agustus & Dead decomposed part of soil & Navagam, malsamot \\
\hline & & & campestris & Soil & Timbapada \\
\hline & & & bisporus & Dead decomposed part of soil & Timbapada, malsamot \\
\hline & & & impudicus & Dead decomposed part of soil & Netrang \\
\hline & & & trisulpharatus & Dead decomposed part of soil & Navagam, sagai \\
\hline & & & Blazei & Soil & Sagai \\
\hline & & \multirow{2}{*}{ Lepiota } & Cristata & Dead decomposed part of soil & Zhadoli \\
\hline & & & atrodisca & Dead decomposed part of soil & Zhadoli \\
\hline & & \multirow{5}{*}{ Leucoagaricus } & rubrotinctus & Dead decomposed part of plant material & Malsamot \\
\hline & & & americanus & Dead decomposed part of plant material & Malsamot \\
\hline & & & melanotrichus & Dead decomposed part of plant material & Sagai, kokam, fulsar \\
\hline & & & nympharum & Dead decomposed part of plant material & Kokam, fulsar, saribar \\
\hline & & & tangerinus & Dead decomposed part of plant material & Devmogra, \\
\hline & & \multirow{4}{*}{ Leucocoprinus } & cretaceus & Base of neem stem. & Kokam \\
\hline & & & birnbaumii & Dead wood of teak & $\begin{array}{l}\text { Sagai, kokam, fulsar,malsamot, } \\
\text { ninaidhodh }\end{array}$ \\
\hline & & & cepaestipes & Dead decomposed part of plant material & Sagai, kokam \\
\hline & & & fragilissimus & Dead decomposed part of plant material & Sagai, kokam, dumkhal \\
\hline & & Podaxis & Pistillaris & Soil & Zhadoli \\
\hline & & \multirow{2}{*}{ Macrolepiota } & Procera & In agricultural field (Soil) & Navagam, sagai \\
\hline & & & clelandii & Soil & Fulsar, Vandri,dediapada \\
\hline & & Lycoperdon & perlatum & Soil & Sagai,Shoolpaneshwar Wildlife Sanctuary \\
\hline 2 & Auriculariaceae & Auricularia & polytricha & Bark of tree (Mango, Butea etc.) & $\begin{array}{l}\text { Kokam,Shoolpaneshwar Wildlife } \\
\text { Sanctuary }\end{array}$ \\
\hline \multirow[t]{3}{*}{3} & \multirow{3}{*}{ Bolbitiaceae } & Canocybe & pubescens & Cow dung and and house & Fulsar, vandri, kokam \\
\hline & & \multirow{2}{*}{ Panaeolus } & papilionaceus & Cow dung & andu \\
\hline & & & sphinctrinus & Cow dung & Fulsar, vandri, kokam \\
\hline 4 & Boletaceae & Phylloporus & rhodoxanthus & Soil & Fulsar, vandri, kokam \\
\hline
\end{tabular}


International Journal of Research in Advent Technology, Vol.7, No.5, May 2019

E-ISSN: 2321-9637

Available online at www.ijrat.org

\begin{tabular}{|c|c|c|c|c|c|}
\hline 5 & Geastraceae & Geastrum & saccatum & Dead and decomposed part of Bamboo & \\
\hline 6 & Gomphaceae & Ramaria & Stricta & wood & Devmogra, mosit \\
\hline 7 & Hymenogastraceae & Galerina & marginata & Cow dung wall & Sagai,Shoolpaneshwar Wildlife Sanctuary \\
\hline 8 & \multirow{5}{*}{ Lyophyllaceae } & \multirow{5}{*}{ Termetomyces } & Heimii & Soil & $\begin{array}{l}\text { Saribar, Kokam, Dumkhal, Sagai, } \\
\text { Devmogra,Fulsar }\end{array}$ \\
\hline & & & globulus & Soil & $\begin{array}{l}\text { Saribar, Chuli, Kokam, Dumkhal, Sagai, } \\
\text { Devmogra }\end{array}$ \\
\hline & & & Eurhizus & Soil & $\begin{array}{l}\text { Saribar, Kunbar, Kokam, Dumkhal, } \\
\text { Devmogra,Fulsar }\end{array}$ \\
\hline & & & albuminosus & Soil & $\begin{array}{l}\text { Saribar, kunbar, Kokam, Dumkhal, Sagai, } \\
\text { Devmogra,Fulsar }\end{array}$ \\
\hline & & & microcarpus & Soil & $\begin{array}{l}\text { Saribar, kunbar, Kokam, Sagai, } \\
\text { Devmogra,Fulsar }\end{array}$ \\
\hline \multirow[t]{6}{*}{9} & \multirow{6}{*}{ Marasmiaceae } & \multirow{6}{*}{ Marasmius } & capillaris & Dead leaves & $\begin{array}{l}\text { Sagai, kokam, fulsar,malsamot, } \\
\text { ninaidhodh }\end{array}$ \\
\hline & & & Oreades & Dead and decomposed part & Sagai, kokam \\
\hline & & & haematocephalus & Dead part of small wood or leaves & Sagai, kokam, dumkhal \\
\hline & & & Sicus & Dead leaves & Sagai, kunbar, fulsar \\
\hline & & & Rotula & Dead bark and leaves & Sagai, kokam, fulsar, kunbar \\
\hline & & & epiphyllus & Tectona grandis leaves mid rib. & Sagai, kokam, fulsar, nigat \\
\hline 10 & Meruliaceae & Podoscypha & multizonata & Dead stem & $\begin{array}{l}\text { Malsamot,Shoolpaneshwar Wildlife } \\
\text { Sanctuary }\end{array}$ \\
\hline \multirow[t]{3}{*}{11} & \multirow{3}{*}{ Nidulariaceae } & \multirow{3}{*}{ Cyathus } & Striatus & Decomposing part of wood & Navagam, malsamot \\
\hline & & & Olla & Decay of cow dung & $\begin{array}{l}\text { Timbapada,Shoolpaneshwar Wildlife } \\
\text { Sanctuary }\end{array}$ \\
\hline & & & stercoreus & Decomposing part of cow dung wall & Timbapada, malsamot \\
\hline \multirow[t]{2}{*}{12} & \multirow[b]{2}{*}{ Phallaceae } & Phallus & impudicus & Decomposed par soil & Dediapada, korvi \\
\hline & & lleodictyon & cibarium & Soil & $\begin{array}{l}\text { Saribar, Kunbar, Kokam, Dumkhal, Sagai, } \\
\text { Devmogra,Fulsar }\end{array}$ \\
\hline \multirow[t]{3}{*}{13} & \multirow{3}{*}{ Physalacriaceae } & \multirow{3}{*}{ Strobilurus } & trullisatus & Dead part of leaf or wood & Sagai, saribar \\
\hline & & & tenacellus & Dead part of leaf or wood & Sagai, malsamot, kokam \\
\hline & & & albipilatus & Dead part of leaf or wood & Saribar, ghatoli \\
\hline \multirow[t]{3}{*}{14} & \multirow{3}{*}{ Pleurotaceae } & \multirow{3}{*}{ Pleurotus } & pulmonarius & Dead part of wood or stem & Sagai \\
\hline & & & ostreatus & Dead part of wood or stem & Fulsar, vandri, kokam \\
\hline & & & Dryinus & Dead part of wood or stem & Kokam \\
\hline
\end{tabular}


International Journal of Research in Advent Technology, Vol.7, No.5, May 2019

E-ISSN: 2321-9637

Available online at www.ijrat.org

\begin{tabular}{|c|c|c|c|c|c|}
\hline \multirow[t]{3}{*}{15} & \multirow{3}{*}{ Pluteaceae } & \multirow{3}{*}{ Pluteus } & Cervinus & Dead and decomposing stem & Sagai, kokam, fulsar \\
\hline & & & salicinus & Dead and decomposing stem & Kokam, fulsar, saribar \\
\hline & & & petasatus & Decomposed part & $\begin{array}{l}\text { Devmogra, Shoolpaneshwar Wildlife } \\
\text { Sanctuary }\end{array}$ \\
\hline \multirow[t]{11}{*}{16} & \multirow{11}{*}{ Psathyrellaceae } & \multirow{2}{*}{ Parasola } & plicatilis & Soil & $\begin{array}{l}\text { Fulsar, Shoolpaneshwar Wildlife } \\
\text { Sanctuary }\end{array}$ \\
\hline & & & Lacteal & Soil & $\begin{array}{l}\text { Navagam,Shoolpaneshwar Wildlife } \\
\text { Sanctuary }\end{array}$ \\
\hline & & \multirow{3}{*}{ Coprinellus } & Lobatum & Decomposed part & Kokam, fulsar, saribar \\
\hline & & & meredithiae & Decomposed part & Devmogra, \\
\hline & & & plicatilis & Decomposed part & Near surpaneshwar sanctury \\
\hline & & Coprinopsis & Cinereal & Cow dung & Sagai, kokam, fulsar, nigat \\
\hline & & Cystoagaricus & trisulphuratus & Dead and decomposed part & $\begin{array}{l}\text { Netrang,Shoolpaneshwar Wildlife } \\
\text { Sanctuary }\end{array}$ \\
\hline & & Psathyrella & candolleana & Soil & Near surpaneshwar sanctury \\
\hline & & \multirow{2}{*}{ Coprinus } & xanthotrix & Decomposed part & Dumkhel \\
\hline & & & Comatus & Cow dung & Dumkhel \\
\hline & & Parasola & plicatilis & Decomposed part & $\begin{array}{l}\text { Kokam, Dumkhal, Sagai, Shoolpaneshwar } \\
\text { Wildlife Sanctuary }\end{array}$ \\
\hline 17 & Repetobasidiaceae & Cotylidia & diaphana & Dead part of stem & Sagai, saribar \\
\hline 18 & Thelephoraceae & Thelephora & Palmata & Dead stem & Saribar \\
\hline 19 & Tricholomataceae & Lepista & Nuda & Soil & $\begin{array}{l}\text { Saribar, Tabda, Kokam, Dumkhal, Sagai, } \\
\text { Devmogra,Fulsar }\end{array}$ \\
\hline
\end{tabular}

